\title{
Impact of Exchange Rate on Economic Growth of Bangladesh
}

\author{
Md. Fazlul Huq Khan
}

\section{ABSTRACT}

\begin{abstract}
This paper investigates the impact of inflation, nominal exchange rate, foreign direct investment, and unexpected event shock on the economic growth of Bangladesh by using the time series data from 1990 through 2020 . Augmented Dickey-Fuller and Phillips-Perron Unit Root Test used to identify unit-roots existence and check the stationary of variables. The Ordinary Least Squares method is applied to determine the relationship between the dependent variable and independent variables. The results revealed that the exchange rate and foreign direct investment have significantly affected the country's economic growth. Inflation, FDI, and exchange rate positive impact, whereas unexpected events like Covid-19, natural disasters, etc., negatively affect the economic development of Bangladesh. The study can be helpful for the policy makers to identify, formulate and implement the effect policies for the economic growth of the country.
\end{abstract}

Keywords: GDP, Inflation, Bangladesh, Exchange rate, COVID-19.
Submitted : May 18, 2021

Published : June 10, 2021

ISSN: 2507-1076

DOI: $10.24018 /$ ejbmr.2021.6.3.891

\section{Md. Fazlul Huq Khan}

School of International Trade and Economics, University of International Business and Economics, Beijing, China.

(e-mail: fazlul.khan @outlook.com)

\section{INTRODUCTION}

The relationship between the exchange rate and the economic rate is one of the substantial fields of study in economics. The exchange rate is defined as the value of one nation's currency compared to other nations' value. The exchange rate measures the amount of foreign product purchase using domestic currency. The nominal exchange rate is adjusted for inflation, whereas the real exchange rate is not. The exchange rate can be expressed in bilateral and multilateral terms. The real exchange rate measures the shortterm volatility of the exchange rate. Most of the countries have floating exchange rates where market forces determine the exchange rate. In a fixed exchange rate, the country's central bank fixes a certain rate in which foreign currencies are exchanged against domestic currency. The combination of the fixed and floating exchange rate is known as managed floating exchange rate.

The primary objective of this paper is to identify the relationship between the exchange rate and the economic growth of Bangladesh. The article also discussed the impact of COVID-19 on the exchange rate and economic growth. This pandemic outbreak has significantly affected economic sectors all over the world, and Bangladesh is no exception. In theory, it is assumed that there is a positive relationship between the exchange rate and economic growth. The devaluation of domestic currency fuels economic growth and encourages exporters. Bangladesh is one of the top exporters of Readymade Garments (RMG) globally, and over $80 \%$ of its total export revenues come from the sector. Although the imports are also relatively high for the country, it is witnessing a declining trend in recent years. The trade balance of Bangladesh remains negative for many years, but due to a large remittance flow, the current account remains positive.

Bangladesh adopted the floating exchange rate system on May 30, 2003, by abandoning the adjustable pegged system. The transition to the floating regime was smooth, experiencing a depreciation of less than 1 percent from June 2003 to April 2004. The market forces played a critical role in determining and stabilizing the exchange rate in later years. The adaption of the floating exchange rate has a positive impact on the country's foreign trade. Exporters and importers can adjust prices and costs following global events, which affects the exchange rate. The Bangladeshi TAKA depreciated very slowly over the years to support the exporters and enhance economic growth. Bangladesh is experiencing a stable exchange rate over the years that results in exponential economic growth and prosperity.

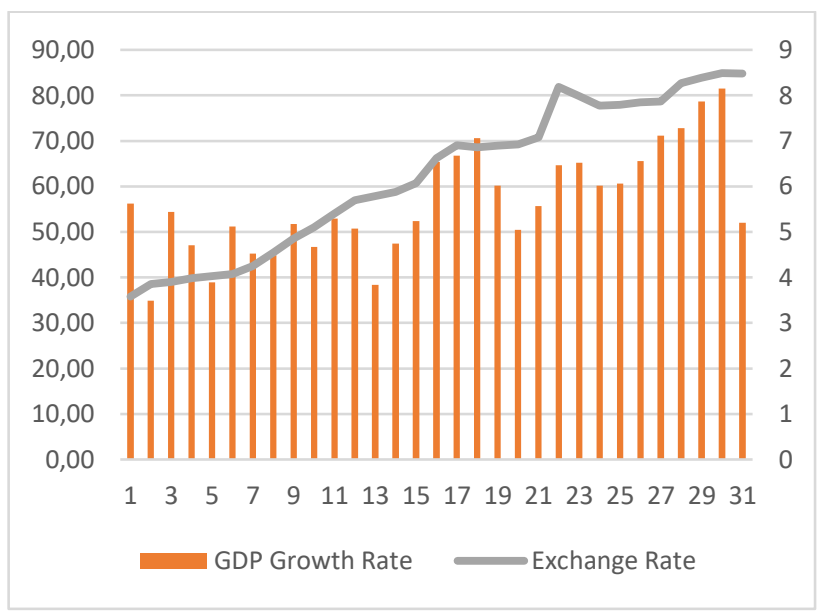

Fig. 1. Economic Growth VS Exchange Rate in Bangladesh. 


\section{LITERATURE REVIEW}

Several researchers try to understand the relationship between foreign exchange and economic growth. All these papers are conducted in various timeframes and geography.

Ahmad [1] examines the relationship between GDP and total investment in Pakistan for 1971-2011. The author uses time-series data and conducts ordinary least square regression to identify the relationship where he finds a significant positive relationship between the two variables. The author concludes that foreign and domestic investment are major economic growth factors, and a stable exchange rate facilitates foreign direct investments.

$\mathrm{He}$ [9] researches to find out the relationship between exchange rate and economic growth in China. The author concludes that due to fixed exchange rate policy adopted by the People's Bank of China enhances the country's economic growth. He also finds that exchange rate volatility fuels longrun productivity and economic growth. The result is similar to what Hussain [10] but contrary to Musyoki [19] finds.

Bakaar [5] investigates the impact of real effective exchange rate on the economic growth of Sierra Leone by using quarterly data of 1990-2006. Using Granger causality tests, he revealed a positive correlation between the country's real effective exchange rate and economic growth. Exploring similar research in five Asian countries, Yin-Wong [23] also finds similar results. Jinzhao [13] uses data from 1992 through 2008 to point out the exchange rate and economic growth correlation within 28 Chinese provinces. The authors conclude that there exists a significant positive relationship between these two variables.

Inflation is also closely correlated with the volatility of the exchange rate and economic growth. Ahmad [2] researches to find the relation between inflation and gross domestic product of Pakistan for 1971-2011. He identifies that inflation has a positive impact on GDP growth by encouraging productivity and output. The author also finds that moderate inflation is better for economic advancement. Hussain [11], Naseer [20], Mubarik [18] and Alam, et.al. [4] also conclude similar remarks in their studies. However, Bruno and Easterly [7], Huybens and Smith [12], Quartey [24], Gosh [8], and Barro [6] found a negative but significant correlation between these two variables. In another study, Ahmad [2] concludes that there is no relationship between inflation and economic growth.

Foreign direct investment is crucial for the growth of the economy. The majority of the researchers found that FDI has a strong and positive impact on economic growth. Ahmad [1] conducted research in Pakistan to identify the impact of FDI on economic advancement. The study found that the flow of FDI is crucial for the sustainable growth of the country. The author finds a significant positive relation between FDI and economic growth. Similar results were found by Mahmood [15], Khaliq [14], Niazi [21] and Mohammad, \& Mohammad [16] in their research.

The economic growth of a country can also be impacted by an unexpected event like a pandemic, natural disasters, etc. In December 2019, an infectious disease named Coronavirus disease 2019 (COVID-19) originated from China affected the global arena. Over 200 countries and territories around the world have been affected by this infectious disease. So far, around 150 million people have been affected by COVID-19, and around 1.9 million people have died worldwide. This unprecedented event can have a substantial impact on economic growth and prosperity. The unemployment rate has skyrocketed, and businesses were forced to shut down due to a liquidity crisis [3]. Bangladesh's economy also took a direct hit from this pandemic, and the growth rate dropped substantially in 2020. Firms always search for the optimization of profits with highest efficiency. [22]. When the foreign exchange rate is favorable, foreign direct investment increases. In recent years, Bangladesh faced a refugee crisis from the neighboring state Myanmar. This unexpected event can trigger a social, political, and economic crisis for the country [17].

\section{DATA AND Methodology}

\section{A. Data}

The research used secondary data collected from the Bangladesh Bank, World Bank, and International Monetary Fund database for 1990-2020. The GDP growth rate is the dependent variable, and the Nominal Exchange rate, Foreign Direct Investment, inflation, and a dummy variable for a pandemic has been used. These variables are used in the majority of the prior studies.

\section{B. Empirical Model}

In this study, the time series data estimations allow to control for observable and unobservable heterogeneity. The specification of the empirical model is:

$$
\mathrm{GDP}_{\mathrm{j}}=\beta_{0}+\beta_{1} \mathrm{INF}_{\mathrm{j}}+\beta_{2} \mathrm{EXH}_{\mathrm{j}}+\beta_{3} \mathrm{FDI}_{\mathrm{j}}+\beta_{4} \mathrm{PAN}_{\mathrm{j}}+\mathrm{e}_{\mathrm{j}}
$$

where GDP implies Economic growth rate, INF is the inflation rate, EXH indicates the nominal exchange rate and FDI means foreign direct investment as percentage of GDP. To linearize the model all the variables are converted in the natural $\log$ form.

The study used Augmented Dickey-Fuller Test and Phillips-Perron Unit Root Test to identify unit-roots existence. Phillips and Perron have generalized the Augmented Dickey-Fuller tests to the situations where the disturbance process in error term is serially correlated. The Phillips-Perron test is intended to add a 'Correction Factor' to the Augmented Dickey-Fuller test statistic.

\section{Empirical Results and Analysis}

The Augmented Dickey-Fuller Test and Phillips-Perron Unit Root Test find that the variables are stationary and automatically cointegrated. So there exists a relationship between the independent and dependent variables. The $\mathrm{p}$ values for both variables in ADF and PP tests are less than the significance level of $5 \%$. As a result, we reject the null hypothesis of non-stationarity. All the variables are integrated of order zero, so the Ordinary Least Square method is appropriate for the analysis.

The results of the OLS exhibits that inflation have a positive but insignificant relationship with GDP growth. Several studies have found that moderate inflation is good for the economy and encourages local producers. The nominal exchange rate has a positive and significant impact on economic growth. The weakened domestic currency attracts 
new investments from home and abroad and creates new investments and employment. Foreign direct investment has a direct positive and significant relationship with the economic growth of Bangladesh. A strong net inflow of FDI creates investments, employments, and output. The majority of the previous researchers also reached a similar conclusion. An unexpected event like a pandemic outbreak has a negative relationship with economic growth. The outbreak of Covid19 reduced the economic growth in almost all the countries in the world. The regression results depicted the current economic situation of the country.

\begin{tabular}{ccccc}
\multicolumn{5}{c}{ TABLE I: ORDINARY LEAST SQUARE (OLS) SUMMARY } \\
\hline Variables & $\begin{array}{c}\text { Estimate } \\
(\text { Std. Error) }\end{array}$ & $\begin{array}{c}\text { Mean } \\
\text { (Std. Dev.) }\end{array}$ & Min & Max \\
\hline GDP & N/A & $\begin{array}{c}1.7125 \\
(0.2087)\end{array}$ & 1.2485 & 2.0983 \\
& 0.0484 & 1.7320 & 0.6967 & 2.4331 \\
INF & $(0.0653)$ & $(0.4281)$ & & \\
& $0.6666^{*}$ & 4.0957 & 3.5776 & 4.4414 \\
EXH & $(0.2048)$ & $(0.2850)$ & & \\
& $0.0222^{*}$ & -1.2874 & -5.4055 & 0.5512 \\
FDI & $(0.0312)$ & $(1.8025)$ & & \\
& -0.2999 & N/A & N/A & N/A \\
\hline
\end{tabular}

*5\% Significance Level.

\begin{tabular}{ccccc}
\multicolumn{5}{c}{ TABLE II: CORREATIONAL ANALYSIS } \\
\hline GDP & EXH & INF & FDI \\
\hline GDP & 1.00 & & & \\
EXH & 0.6178 & & & \\
INF & 0.3306 & 0.3152 & & \\
FDI & 0.6186 & 0.6632 & 0.2902 & \\
PAN & -0.056 & 0.2243 & -0.0001 & -0.0152 \\
\hline
\end{tabular}

\section{CONCLUSION}

This study examines the impact of inflation, exchange rate, foreign direct investment, and unexpected event shock on the economic growth of Bangladesh by using the yearly data for the period of 1990-2020. The results from multiple regression imply that exchange rate and foreign direct investment have significantly affected the country's economic growth. Among the variables, inflation, FDI, and exchange rate positive impact whereas unexpected event like Covid-19, natural disasters, etc., negatively affect the economic growth. Controlling the inflation level is crucial for the country as it directly impacts the interest rates and exchange rate. A strong domestic currency discourages foreign investors and exports, which in turn reduces the domestic output. The model used in the research, free from heteroskedasticity, autocorrelation, and functional, is up to the mark to prove the stability of the model. The model structurally viable and adjusted for all the outliers to control spurious correlations. The country's policymakers should focus on formulating and adjusting the necessary policies required to enhance economic growth and development.

\section{REFERENCES}

[1] Ahmad, N. (2012). A dynamic analysis of the relationship among inflation, investment, population growth, export and economic growth in Pakistan. Asian Journal of Research in Business Economics and Management, 175-182.

[2] Ahmad, N. (2012). The causal links between foreign direct investment and economic growth in Pakistan.European Journal of Business and Economics, 20-21.

[3] Ahamed, F. (2021). Macroeconomic Impact of Covid-19: A case study on Bangladesh. IOSR Journal of Economics and Finance (IOSR-JEF), 12(1), 2021.

[4] Alam, M. M., Khondker, R. K. and Molla, M. S. (2013) "Current Account Dynamics, Adjustment and Capital Mobility in Bangladesh", Global Disclosure of Economics and Business, 2(2), pp. 117-126. doi: 10.18034/gdeb. v2i2.180.

[5] Bakaar, T. (2010). Real exchange behaviour and economic growth: evidence from Sierra Leone. SAJEMS NS 13 (2010) NO 1, 08-23.

[6] Barro, R.J. (1995). Inflation and Economic Growth. National Bureau of Economic Research (NBER) Working Paper No. 5326.

[7] Bruno, $M$ and Easterly, W. (1998). Inflation crises and long-run growth. Journal of Monetary Economics, 03-26.

[8] Ghosh, A. (1998). Warning: Inflation May Be Harmful. International Monetary Fund, 662-710.

[9] He, Q. (2010). Expanding varieties in the nontraded goods sector and the real exchange rate depreciation. Journal of international and global economic studies, 19-38.

[10] Hussain, F. (2009). Economic growth and exchange rate volatility in case of Pakistan. Pakistan Journal of life and social sciences, 112-118.

[11] Hussain, S. (2011). Inflation and Economic Growth: Evidence from Pakistan. International Journal of Economics and Finance, 262-276.

[12] Huybens, E. and Smith, B. (1999) Inflation, Financial markets and long run real activity. Journal of Monetary Economics.

[13] Jinzhao, C. (2012). Real exchange rate and economic growth: evidence from Chinese Provicial data (1992-2008). Paris School of Economics Working paper No: 2012-05, 01-27.

[14] Khaliq, A. (2007). Foreign Direct Investment and Economic Growth: Empirical Evidence from Sectoral Data in Indonesia. Indonesia Journal and Review, 01-27.

[15] Mahmood, I. (2011). Macroeconomic variables and FDI in Pakistan, European Journal of Scientific Research, 388-393.

[16] Mohammad, M. A., \& Mohammad, R. I. (2010). Revisiting the Feldstein-Horioka Hypothesis of savings, investment and capital mobility: evidence from 27 EU countries.

[17] Minar, S. J. (2019). Tatmadaw's Crackdown on The Rohingyas: A SWOT Analysis. Journal of Social Studies, 5(1), 1-5.

[18] Mubarik, Y. (2005). Inflation and Growth: An Estimate of the. SBPResearch Bulletin, 35-44.

[19] Musyoki, D. (2012). The impact of real exchange rate volatility on economic growth: Kenyan evidence. Business and Economic Horizons, 59-75.

[20] Naseer, L. (2012). Secondary Education and Economic Growth in Developing Countries: A Case Study of Pakistan. Interdisciplinary Journal of Contemporary Research In Business, 306-313.

[21] Niazi, G. (2011). Does an Inflation and Growth of a country affect its Foreign Direct Investment? Journal of Management, Economics \& Finance, 84-90.

[22] Pramanik, P. (2020, December). Optimization of Market Stochastic Dynamics. In SN Operations Research Forum (Vol. 1, No. 4, pp. 1-17). Springer International Publishing.

[23] Yin-Wong, C. (1998). Economic growth and stationarity of real exchange rates: Evidence from some fast-growing Asian Countries. Pacific Basin Finanace Journal, 61-76.

[24] Quartey, P. (2010). Price Stability and the Growth Maximizing Rate of Inflation for Ghana. Scientific Research Journal, 180-194.

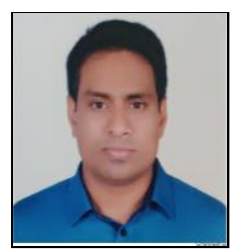

Md. Fazlul Huq Khan is a Ph.D. candidate at the School of International Trade and Economics, University of International Business and Economics, Beijing, China. He has ten years of experience working in the Central bank of Bangladesh. The author possesses the expertise of formulating and implementing the economic policies of the country. Previously he did Bachelor of Business Administration (B.B.A.) in Management and Master Of Business Administration (M.B.A.) in Human Resources Management from the University of Dhaka. 